УДК 347.61/.64

DOI https://doi.org/10.32837/pyuv.v0i2(31).561

\author{
А. Л. Калінюк \\ orcid.org/0000-0001-8032-3632 \\ старший викладач кафедри цивільного права і процесу \\ Національної академії внутрішніх справ
}

\title{
ПРАВО ВІТЧИМА, МАЧУХИ НА ВИХОВАННЯ ПАСИНКА, ПАДЧЕРКИ ЗА СІМЕЙНИМ ЗАКОНОДАВСТВОМ УКРАЇНИ
}

Конвенція ООН про права дитини, яку було прийнято в 1989 р. та ратифіковано Україною в 1991 р., проголошуе, що для повноцінного розвитку дитині найкраще зростати в сім'ї, в атмосфері щастя, любові та взаєморозуміння [1]. Сім'я є природним середовищем для фізичного, духовного, інтелектуального, культурного, соціального розвитку дитини, іiі матеріального забезпечення [2]. Інститут сім'ї ми сприймаємо за першооснову нашого буття, за обов'язкову ланку нашої життєдіяльності, розвитку і функціонування в суспільстві.

Дослідники підкреслюють, що сім’ї належить основна роль у формуванні моральних засад, життєвих принципів дитини. Велике значення для їі емоційної врівноваженості та психічного здоров'я має стабільність сімейного середовища [3, с. 144]. Тому й держава забезпечує пріоритет сімейного виховання [4].

На жаль, останнім часом дедалі більше поширюється таке негативне явище, як «криза сім'ї, що проявляється в різних сферах: духовній, моральній, соціальній, виховній, правовій та ін. На кризове становище вказує також нестабільність інституту сім'ї: простежується стійка тенденція розпаду сім'ї та сімейних стосунків, створення нових сімей через незначний період часу. Має місце виникнення нових сімейних відносин за участю нерідних батьків і дітей. Все це викликає потребу, серед іншого, відповідного правового регулювання особистих і майнових правовідносин за участю вітчима, мачухи та пасинка, падчерки.

Тема особистих немайнових прав батьків і дітей не є новою для науки сімейного права. Такі вчені, як С.П. Індиченко, В.І. Борисова, В.С. Гопанчук, І.В. Жилінкова, О.Ю. Казанцева, О.М. Калітенко, Л.В. Красицька, Н.М. Крестовська, Б.К. Левківський, В.П. Мироненко, Л.В. Ольховик, Г.О. Резнік, З.В. Ромовська, Л.А. Савченко, І.Л. Сердечна, Я.М Шевченко та ряд інших приділили увагу розгляду широкого спектру питань щодо змісту прав батьків, видів і їхніх ознак, підстав виникнення та припинення. Проте проблематика права вітчима, мачухи (нерідних батьків) на виховання пасинка, падчерки (нерідних дітей) залишається малодослідженою, оскільки розглядається в загальному вигляді й у сукупності із правами й обов'язками інших членів сім'ї.
Метою статті є з'ясування поняття та змісту права вітчима, мачухи на виховання пасинка, падчерки, а також питання щодо правового регулювання цього права за сімейним законодавством України.

У чинному сімейному законодавстві України, крім виховання дитини у сім'ї у класичному розумінні, чітко врегулюванні ще й такі форми сімейного виховання, як: усиновлення; встановлення опіки та піклування; прийомна сім'я; дитячий будинок сімейного типу; патронат. Суб'єктами, на яких покладено право й одночасно обов'язок виховання, закон називає батьків, близьких родичів дитини, прийомних батьків, батьків-вихователів, патронатних вихователів, а також вітчима, мачуху.

Розглядаючи це питання, слід наголосити на тому, що сімейні правовідносини за участю вітчима, мачухи складаються у сім'ях, створених на основі повторного шлюбу жінки та чоловіка, або так званих змішаних, відтворених чи реструктиризованих сім'ях. Йдеться саме про ті відносини, де фактичну функцію батька, матері щодо виховання дитини перебирає на себе вітчим, мачуха. $\mathrm{y}$ цьому сенсі не можемо не погодитися із 3.В. Ромовською, котра, характеризуючи роль фактичних вихователів у житті дитини, зазначала, що, незважаючи на те, що "як тільки не називають мачуху та вітчима, нерідко саме вони ставали воістину матір'ю чи батьком для дитини» [5, с. 380].

Варто також вказати, що виховання в таких змішаних (реструктуризованих) сім'ях є певним викликом для сучасного суспільства, оскільки умови проживання та виховання дитини суттєво змінено. I, як наслідок, виникає безліч питань i проблем, які породжують певні ризики для нормального, гармонійного та повноцінного зростання і розвитку дитини.

Правовою основою регулювання особистих немайнових прав батьків і дітей є Сімейний кодекс України. Відповідні норми задекларовані у главі 13 СК України [4]. Але, як зауважує О. Оніщук, ані у сімейному кодексі, ані в іншому нормативно-правовому акті не міститься визначення батьківських прав. Більше того, батьківські права розглядаються у невід'ємному взаємозв'язку з батьківськими обов'язками, і більшість батьківських прав виводяться крізь призму обов'язків [6, с. 27]. 
Характеризуючи сімейні правовідносини між вітчимом, мачухою та пасинком, падчеркою, I.В. Апопій стверджує, що, коли йдеться про виховання дитини, законодавець передбачив це саме як право вітчима, мачухи, на відміну від усиновлювача, опікуна та піклувальника, для яких виховання дитини є обов'язком. Автор також стверджує, що усиновлювач, опікун і піклувальник свідомо та добровільно шляхом вчинення певних юридичних дій покладають на себе відповідальність за дитину, а вітчим, мачуха набувають свого правового статусу автоматично після реєстраціі шлюбу з батьком, матір'ю дитини. Тобто добровільно приймають права й обов'язки подружжя, а додатково отримують ще і права й обов'язки щодо пасинка, падчерки [7].

У такому контексті ми не можемо повністю погодитися з думкою I.В. Апопій, оскільки із зазначеного вбачається, що у повторному шлюбі основною є побудова шлюбно-сімейних відносин із новими чоловіком, дружиною, а наявність дитини (дітей) від попереднього шлюбу - це вимушена обставина, яка тягне за собою виникнення додаткових прав і обов'язків вітчима, мачухи.

Ст. 260 СК України закріплено право вітчима, мачухи брати участь у вихованні малолітніх, неповнолітніх пасинка, падчерки за умови проживання їх однією сім'єю. У науковій літературі обгрунтовується положення, що підставою виникнення правовідносин між вітчимом (мачухою) і дитиною $€$ фактичні дії, які свідчать про прийняті першим на себе обов'язків по вихованню [8, с. 189]. Більш того, ст. 260 СК України не вказує на таку обов'язкову умову, як спільне проживання з батьком, матір'ю дитини, зазначаючи лише обов'язкове проживання однією сім'єю $з$ дитиною. Тому ми можемо припустити, що у разі тимчасової відсутності або навіть смерті батька, матері дитини право вітчима, мачухи на виховання дитини залишається за останніми як за особами, котрі фактично замінюють батька чи матір.

На наш погляд, чинна норма СК України прописана законодавцем дещо поверхнево, оскільки очевидним $є$ лише факт спільного проживання 3 дитиною, а право на виховання виражається лише в особистому ставленні вітчима, мачухи до виконання батьківських функцій. Виявляється, що для реалізації виховної функції вітчимом, мачухою достатнім може бути проведення бесіди виховного характеру, виявлення звичайного інтересу щодо повсякденних справ дитини у школі або у колі друзів чи однокласників, звичайна прогулянка. 3 одного боку, вітчим, мачуха у таких простих діях взяли на себе батьківську функцію, а з іншого - чи є підстави вважати також взяття на себе саме права на виховання дитини, адже правом на виховання охороняється винятково важливий інтерес батьків, особливо цінне немайнове бла- го - спілкування з дітьми, можливість особистого впливу на них [9, с. 155].

Дуже вдалою уявляється позиція О.Ю. Казанцевої, яка підкреслює, що зазначені особи, навіть проживаючи разом із дитиною, не володіють правом і не зобов'язуються сімейним законодавством до її виховання [10, с. 20]. Хоча в науковій літературі також припускається, що соціальний батько (в нашому випадку - вітчим, мачуха) виконує ті самі батьківські функції, може мати таке саме емоційне ставлення до нерідної дитині, що і біологічний батько [11, с. 174-188].

Отже, для визначення права на виховання дитини вітчимом, мачухою необхідно виокремити такі умови: укладення між вітчимом, мачухою та біологічною матір'ю, батьком дитини шлюбу і спільне проживання, спільне виховання й утримання дітей як рідних, так і пасинка, падчерки.

Вказані умови є обов'язковими і несуть відповідне правове навантаження тільки у своїй єдності. Як стверджує М.В. Бориславська, укладення шлюбу - це лише умова можливості проживання мачухи, вітчима із дитиною, але не їхній обов'язок. Спільне проживання може і не мати місце або настати через деякий проміжок часу після укладення шлюбу. Підставою для виникнення відносин зі спільного проживання мачухи, вітчима 3 падчеркою, пасинком $є$ їхнє реальне проживання у межах однієї сім'ї [12, с. 57]. У цьому контексті ми вважаємо думку вченої цілком справедливою, оскільки в ній відтворюються ознаки сім'ї, закладені в нормуч. 2. ст. 3СК України - сім'юскладають особи, які спільно проживають, пов'язані спільним побутом, мають взаємні права й обов'язки [4].

Крім того, у змішаних сім'ях характер сімейного правовідношення визначається якраз тим, в якій саме якості особа виступає у цьому правовідношенні [8, с. 69-70].

Існування права батьків на виховання Є.М. Ворожейкін відносить до беззаперечних понять у галузі сімейного права. Батьки - природні опікуни своїх дітей, і тому здійснюють права, виконують покладені на них обов'язки без особливого на те повноваження [8, с. 186]. Більш того, ще ст. 99 Руської Правди закріплювала, що якщо після смерті батька в сім’ї залишалися діти і мати знову виходила заміж, то опікуном міг бути вітчим або один із близьких родичів; опікуну передавалося у тимчасове користування майно дітей при свідках; у статті регламентувалися права й обов'язки опікуна [13]. Ось чому батьки сприймають ці права як власне благо, яким можна розпоряджатися на власний розсуд $[14$, с. 19].

У юридичній літературі спостерігаються різні підходи та критерії у визначенні поняття права на виховання. На наш погляд, це зумовлено тим, що право на виховання є комплексним, збірним поняттям, оскільки містить широке коло повнова- 
жень, реалізація яких спрямована на забезпечення проголошеного законодавством права кожної дитини на сімейне виховання. Навіть якщо брати до уваги лише сімейно-правову сферу, як зазначала O.M. Нечаєва, право на виховання включає в себе два різновиди прав залежно від того, хто є їх носієм - батьки чи діти [15, ст. 36].

Досліджуючи можливість права вітчима, мачухи на виховання пасинка, падчерки, ми можемо стверджувати, що це право є суб'єктивним. Суб'єктивне право - це надана особі законом можливість певної поведінки, а також можливість вимагати відповідної поведінки від іншої особи [16, с. 226-227]. Адже, як зазначає Р.0. Стефанчук, коли ми певну правову можливість опосередковуємо поняттям «суб'єктивне цивільне право», то це означає, що вона відповідно до принципу «юридичної синхронності» має усі підстави бути забезпеченою юридичним обов'язком дотримання та не порушення цього права, а невиконання цього обов' язку спричинить появу відповідних правових наслідків у вигляді юридичної відповідальності [17, с. 109].

Тому вбачається, що право на виховання у вітчима, мачухи виникає одночасно 3 моментом виникнення в особи цього суб'єктивного права i незалежно від того, чи бажає уповноважена особа його здійснення [18, с. 15-16]. Водночас згідно із СК України за наявності у вітчима, мачухи відповідного суб'єктивного права на виховання пасинка, падчерки вони можуть обрати варіант можливої поведінки [19, с. 148] - реалізувати дане законом право на виховання або ні.

Право неповнолітнього на належне виховання в сім'ї, по суті справи, єдине, ні з чим незрівнянне право особистого характеру. Головна особливість цього права полягає у тому, що самостійно реалізувати надану можливість духовно розвиватися найбільш сприятливим шляхом дитина не може. Це право реалізовують батьки, виконуючи відповідні обов' язки. Ми поділяємо думку О.Ю. Казанцевої, яка підкреслює, що «обов’язок батьків по вихованню дітей кореспондує праву самих дітей на отримання сімейного виховання. У суб'єктивному праві дітей на виховання «центр тяжіння» знаходиться у праві-вимозі від зобов'язаних осіб вчиняти різноманітні виховні дії» [10, с. 20].

Жодне із передбачених законом особистих прав не знає такого тісного переплетіння, як батьківське право на виховання: право на виховання $€$ одночасно обов'язком, а обов'язок виступає правом. У цьому розумінні Я. Шевченко підкреслює: «Поєднання права й обов'язку батьків щодо виховання дитини викликане особливостями дитини як суб'єкта сімейно-правових відносин, особли-

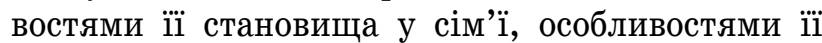
особистості, котра перебуває у процесі фізичного, психічного і морального формування. Роз'єднува- ти право й обов'язок батьків неможливо - за змістом вони однакові, а вираження, з одного боку, в праві, а з іншого - в обов'язку становить сутність відносин між батьками і дітьми» [20, с. 128]. Подібної позиції дотримується й О.Ю. Казанцева, зазначаючи: «Тільки теоретично можливе розділення прав та обов'язків батьків. У житті вони проявляються як єдиний виховний процес у сім'̈і, який організовується і здійснюється батьками. Оскільки одні і ті самі суб’єкти виступають і як правомочні, i як зобов'язані у виховній сфері, то практично неможливо виділити, коли вони здійснюють своє право, а коли виконують обов'язки» $[10$, с. 20$]$.

3 огляду на зазначене правове регулювання особистих немайнових відносин за участю вітчима, мачухи, а саме право на виховання пасинка, падчерки має дуже важливе значення та вимагає юридичного закріплення на рівні закону. Отже, дослідження питання права вітчима, мачухи на виховання пасинка, падчерки дає підстави для таких висновків:

Норма ст. 260 СК України «Право мачухи, вітчима брати участь у вихованні пасинка, падчерки» не відображає повною мірою сутність законодавчо закріплених ознак сімейних правовідносин, оскільки містить лише право мачухи, вітчима брати участь у вихованні пасинка, падчерки, не покладаючи на них відповідний обов' язок. В основу такого висновку покладена неможливість відмежування права й обов'язку в контексті розгляду права на виховання як особистого права.

Свобода вибору у реалізації суб'єктивного сімейного права вітчима, мачухи на виховання пасинка, падчерки не гарантує дитині достатній рівень всебічного, повного розвитку і виховання, що порушує пріоритет сімейного виховання. А реалізація чи здійснення відповідного права залежить лише від рівня особистої відповідальності вітчима, мачухи перед нерідними дітьми.

У зв'язку з цим пропонуємо ст. 260 СК України викласти у такому вигляді: «Права й обов'язки мачухи, вітчима щодо виховання пасинка, падчерки», а зміст зазначеної норми - у такій редакції: «Мачуха, вітчим, які проживають однією сім'єю з малолітніми, неповнолітніми пасинком, падчеркою, мають права й обов'язки щодо їх виховання та захисту відповідно до положень ст. 262 цього Кодексу».

\section{Jimepamypa}

1. Декларація прав дитини (Прийнята резолюцією 1386 (XIV) Генеральної Асамблеї ООН від 20 листопада 1959 р.). URL: https://zakon.rada.gov.ua/laws/ show/995_384\#Text (дата звернення: 20.06.2020).

2. Про охорону дитинства : Закон України від 26 квітня 2001 р. № 2402-III. URL: http://zakon2.rada.gov.ua/laws/show/2402-14 (дата звернення: 20.06.2020). 
3. Попова Л.Г. Восприятие семейной ситуации детьми 7-10-летнего возраста, живущими в разной социальной среде. Известия Уральского фед. ун-та. Сер. 1. Проблемы образования, науки и культуры. 2010. T. 71. № 1. С. 135-144.

4. Сімейний кодекс України : Закон України від 10 січня 2002 р. № 2947-III. Відомості Верховної Ради України. 2002. № 21-22. Ст. 135.

5. Ромовська 3.В. Сімейний кодекс України: Науково-практичний коментар. Київ : Правова єдність, 2009. 432 с.

6. Оніщук О. Поняття та особливості батьківських прав. Підприєлниитво, господарство і право. 2019. № 10. C. $26-30$. DOI https://doi.org/10.32849/2663$5313 / 2019.10 .05$.

7. Апопій I.В. Правовий статус мачухи і вітчима у сімейному праві України. Радник. Український юри дичний портал. URL: http://radnuk.info/statti/567simeine/15158-2011-01-21-09-00-45. html.

8. Ворожейкин E.M. Семейные правоотношения в СССР. Москва : Юрид. лит., 1972. 336 с.

9. Рясенцев В.А. Советское семейное право. Москва : Юрид. лит., 1982.256 с.

10. Казанцева А.Е. Обязанности и права родителей (заменяющих их лиц) по воспитанию детей и ответственность за их нарушение. Томск : Изд-во Томского ун-та. 1987. $144 \mathrm{c.}$

11. Мид М. Мужское и женское. Исследование полового вопроса в изменяющемся мире. Москва : РОССПЭН. 2004. $412 \mathrm{c.}$

12. Бориславська М.В. Проживання падчерки, пасинка разом з мачухою, вітчимом: сімейно-правове значення. Часопис иивілістики. 2014. № 17. С. 56-59.

13. Чистяков О. И. Российское законодательство $\mathrm{X}-\mathrm{XX}$ веков : в 9 т. Москва : Юрид. лит., 1984. Т. 1. Законодательство Древней Руси. 432 с.

14. Нечаева А. Пределы осуществления родительских прав. Сои. законность. 1986. № 7. С. 19-21.

15. Нечаева А.М. Правонарушения в сфере личных семейных правоотношений. Москва:Наука, 1991.238c.

16. Халфина Р.О. Общее учение о правоотношении. Москва : Юрид. лит., 1974. $351 \mathrm{c.}$

17. Стефанчук Р.О. Система особистих немайнових прав фізичних осіб у сфері сімейних відносин: до питання вдосконалення. Університетські наукові запис $\kappa u$. 2006. № 2. C. 107-111.

18. Вавилин Е.В. Осуществление и защита гражданских прав : монография. Российская академия наук. Ин-т государства и права. Москва : Волтерс Клувер, 2009. 360 с.

19. Красицька Л.В. Проблеми здійснення та захисту особистих та майнових прав батьків і дітей : монографія. Київ : Видавництво Ліра-К, 2014. 628 с.

20. Шевченко Я. Проблеми правового регулювання сімейних відносин. Українське право. 1998. № 1. C. $121-130$.

\section{Анотація}

Калінюк А. Л. Право вітчима, мачухи на виховання пасинка, падчерки за сімейним законодавством України. - Стаття.

У статті досліджуються питання права вітчима, мачухи на виховання пасинка, падчерки відповідно до чинного сімейного законодавства України. Автором підкреслюється важливість пріоритету сімейного виховання як основного чинника гармонійного, повного та всебічного розвитку дитини.

Акцентовано увагу на проблемі здійснення права на виховання відповідними суб'єктами сімейних пра- вовідносин у відтворених (змішаних) сім'ях, де фактичні функції щодо виховання дитини поряд із біологічними батьками покладаються і на вітчима, мачуху.

Проаналізовано наукову літературу 3 досліджуваної проблеми, визначено особливості змісту права на виховання вітчимом, мачухою пасинка, падчерки.

Автором обгрунтовується положення про те, що право вітчима, мачухи на виховання пасинка, падчерки є суб'єктивним сімейним правом, оскільки ст. 260 Сімейного кодексу України вітчиму, мачусі законом надана можливість певної поведінки - право брати участь у вихованні пасинка, падчерки. Водночас згідно із Сімейним кодексом України за наявності у вітчима, мачухи відповідного суб'єктивного права на виховання пасинка, падчерки вони самостійно, на свій розсуд, можуть обрати для себе варіант можливої поведінки - реалізувати дане законом право на виховання або ні.

Наголошується, що право на виховання - по суті одне із найважливіших особистих прав дитини, яке вона реалізувати самостійно не може. Це право реалізовують у життя батьки у поєднанні з відповідним обов' язком щодо належного виховання дитини.

Зроблено висновок, що норма ст. 260 Сімейного кодексу України не повною мірою відображає суть і значення правана виховання, покладених навітчима, мачуху, а тому потребує подальшого доопрацювання і зміни.

Автором запропоновано внести зміни до ст. 260 Сімейного кодексу України і викласти її у такому вигляді: «Права й обов'язки мачухи, вітчима щодо виховання пасинка, падчерки", а зміст зазначеної норми - у такій редакції: «Мачуха, вітчим, які проживають однією сім'єю з малолітніми, неповнолітніми пасинком, падчеркою, мають права й обов'язки щодо їх виховання та захисту відповідно до положень ст. 262 цього Кодексу».

Ключові слова: вітчим, мачуха, пасинок, падчерка, особисті права, право на виховання.

\section{Summary}

Kaliniuk A. L. The right of the stepfather, stepmother to upbringing a stepson, stepdaughter with current family law of Ukraine. - Article.

The article analyzes the right of the stepfather, stepmother to upbringing a stepson, stepdaughter in accordance with current family law of Ukraine. The author emphasizes the importance of the priority of family upbringing as the main factor in the harmonious, complete and comprehensive development of a child.

Emphasis is placed on the problem of exercising the right to upbringing by the relevant subjects of family relations in blended (mixed) families, where the actual functions of upbringing a child along with the biological parents are entrusted to the stepfather, stepmother.

The scientific literature on the problem under study is analyzed and the emphasis is on peculiarities of the content of the stepfather's, stepmother's right to bring up a stepson, stepdaughter.

The author substantiates the position that stepfather's, stepmother's right to bring up allows a stepfather, stepmother certain behavior - the right to participate in upbringing of a stepson, stepdaughter. At the same time, according to the Family Code of Ukraine, if a stepfather, stepmother has the appropriate subjective right to bring up a stepson, stepdaughter, they can, at their own discretion, choose a possible behavior - to exercise the legal right to upbringing or not.

The author emphasizes that the right to upbringing is, in fact, one of the most important personal rights of a child, which they cannot exercise on their own. This right 
is exercised by the parents in conjunction with the relevant responsibility for the proper upbringing of a child.

It is concluded that the norm of Article 260 of the Family Code of Ukraine does not fully reflect the essence and importance of the right to upbringing imposed on a stepfather, stepmother, and therefore needs further refinement and change.

The author proposes to amend Article 260 of the Family Code of Ukraine and to state it in the following edition: "Rights and duties of the stepmother, stepfather concerning education of a stepson, stepdaughter", and the content of specified norm - as follows: "the stepmother, stepfather living in one family with little, minor stepsons, stepdaughters have rights and responsibilities for their upbringing and protection in accordance with the provisions of Article 262 of this Code".

Key words: stepfather, stepmother, stepson, stepdaughter, personal rights, right to upbringing. 